\title{
The Relation between Teachers' Perception of Ethical Leadership, Organizational Justice and Organizational Cynicism
}

\author{
Hüseyin Bağrıyanık (Corresponding author) \\ Osmaniye Korkut Ata University \\ 80010, Osmaniye, Turkey \\ Tel: 90-553-854-5231Ｅ-mail: bagriyanik80@gmail.com
}

Niyazi Can

Kahramanmaraş Sütçü İmam University

46050, Kahramanmaraş, Turkey

Tel: 90-533-749-4336 E-mail: niyazican@ksu.edu.tr

Received: Jan. 23, 2017 Accepted: April 4, 2017 Published: May 1, 2017

doi:10.5296/jse.v7i2.10973 URL: https://doi.org/10.5296/jse.v7i2.10973

\begin{abstract}
The purpose of this study is to examine the relation between middle school teachers' perception of ethical leadership, organizational justice, and organizational cynicism. Participants of the study are teachers from schools located in Osmaniye downtown in 2014-2015 academic year. These schools were chosen randomly by using simple random sampling method and 386 teachers working in these schools were participants of this study. Data were gathered by using "Ethical Leadership Scale", "Organizational Justice Scale" and "Organizational Cynicism Scale". In this study, relational scanning method was used. Study shows that there is a positive and significant relation between teachers' ethical leadership perception and organizational justice. However, ethical leadership and organizational justice have a negative significant relationship. Results show that the relation between all sub dimensions is significant. Ethical leadership and organizational justice are predictors of the organizational cynicism. Besides, it is resulted that organizational justice has a mediator role between ethical leadership and organizational cynicism.
\end{abstract}

Keywords: Ethical Leadership, Organizational Justice, Organizational Cynicism, Teachers, Schools. 


\section{Introduction}

In the mechanism of educational institutions, ethic notion has a special significance for teachers and school leaders. Ethic is defined as moral principals in the working environment that defines good and bad (Hatcher, 2004). If an individual aim to be a significant, effective and valuable school leader, she/he should be ethics, morality and value centered (Parent, 2009). This manner results in different kind of leadership: ethical leadership, distributed leadership, spiritual leadership and value based leadership. However, ethical leadership, which includes morality, ethic and value notions, can be more effective in a school mechanism. Ethical leaders make organization's values and goals concrete, focus on organizational success, produce value for stakeholders and create mechanism for creative thinking (Brown \& Trevino, 2006). In this dimension, teachers' perception of ethical leadership towards school leaders has a significant effect on many behaviors such as faith, cynicism and justice. In this aspect, teachers' ethical perception towards school leaders has a great impact on organizational behavior like leadership perception, cynicism and justice.

Being fair is an important trait that should be performed always for a leader because in an organization when fairness is the focus, employees' behaviors are affected by this (Y1ldirım, 2010). In the process of leadership, organizational justice has an important role (Pillai, Scandura \& Ethlyn, 1999). During the education period, managers should be able to make a fair responsibility sharing and mission sharing because teachers' leadership perception towards school leaders affects teachers' behaviors and attitudes towards many responsibilities. In the school environment, teachers having similar role compare themselves with other teachers. If teachers feel they experience an unjustness, they can perform unwanted attitude and behavior both in school and out of the school. Andersson and Bateman (1997) defines cynicism as negative and insecure attitude towards authority and institutions. Cynicism is a condition that appear as contemptuous and critical attitude as a result of negative experiences and feelings(Karacaoğlu\& İnce, 2013: 186). In the other words, cynicism is hopelessness, disappointment and frustration for an individual, group, ideological idea, institution or organization (Andersson, 1996). Almost all organizations have cynics employees. This led cynicism to be examined in organizational level in recent years (James, 2005:6). Organizational cynicism appears as a result of the thought that functioning of the organization is deprived of moral principles like fairness and sincerity and these principles are neglected for the interest of the organization (Bernerth, Armenakis, Feild \& Walker, 2007). This situation affects organization negatively and decreases their sustainability.

As a result, teachers' perception of ethic leadership toward school leaders is determinant of many factors like organizational justice and organizational cynicism (Yidong\&Xinxin, 2013; Y1ldirım, 2010). Appearance of these behaviors is directly related with managers' behaviors quality of ethicalness. In this study, it is aimed to contribute school leaders' behaviors by examining the effect of teachers' perception of ethical leadership on level of organizational justice and organizational cynicism.

\subsection{Ethical Leadership}

Ethical leadership embodies organization's goals, vision and values in an ethical understanding (Freeman\& Stewart, 2006). Ethical leadership is related with honesty, trust, 
respect (Brown, Trevino \& Harrison, 2005). In the same time, it is defined as performing acceptable behaviors as an individual, in interpersonal communication, managing subs by supporting and making decisions (Hansen, 2011). Greenfield considers ethical leaders as an individual who has a powerful impression on teacher and helps teachers for improving job vocational goal (Çelik, 2013). Ethical leadership is composed of four main categories: climatic, communicational, behavioral and decisional ethic. Climatic ethic consists of behaviors like that managers promotes subs, giving concrete goals, making rule of the intuition in a proper way. Communicational ethics consist of behaviors like accepting own failures, not being selfish, being fair, being constructive in discussions, being patient, fair, respectful, sincere and modest. Behavioral ethic consists of behaviors like self-awareness, being veracious, honest and courageous, protecting individual rights and being respectful for values (Y1lmaz, 2005). Decisional ethic examines behaviors in terms of making morally correct decisions, to be able to differentiate what is correct and what is wrong, and being ethical in making decision (Turhan, 2007).

\subsection{Organizational Justice}

Organizational justice is a notion that includes relations of employee- manager relations, colleague relations and as social system of organization; socially and economically all mutual interaction like missions in the organization, salary, prize, punishment, promotion (Özkalp\&Kirel, 2004). Folger \&Cropanzano(1998) explains 'organizational justice' notion, how should be distribution of organizational resources, procedures that are using for distribution of resources and how should be the interaction that occurs during implementation of the decision. Distributive justice is related with managers' honesty and fairness in distributing organization's resources. Interactional justice is related with being honest and fair in making decisions, planning and implementation of the plans (Eren, 2015). Operational justice is related with criteria like employees' right for attending decision making process, correctness of shared information, possibility of fixing mistakes, feasibility of rules (Greenberg,2011).

\subsection{Organizational Cynicism}

Organizational cynicism can be defined as employees' hopelessness, disappointment and negative attitude about organization (Andersson, 1996), an individual's negative attitude towards organization that she/he is working (Bedeian, 2007), an employee's negative attitude, based on the belief that organization is against his/her personal interest, toward his/her organization's procedure, process and management (Wilkerson, Evans \& Davis, 2008: 533). Cognitive cynicism covers all the information, experience, belief and thought that related with people, event, situation, and object around an individual (İnceoğlu, 2004: 26). Affirmative cynicism is related with notions towards organization like disrespect, anger, boredom and shame (Abraham, 2000). In the dimension of behavioral cynicism, it most of the time includes humiliating and negative inclinations. Cynic behaviors in the organization contains behaviors inclined mocking, different from self-recognizable behaviors (Dean, Brandes, \&Dharwadkar, 1998). 


\subsection{Purpose of the Study}

Purpose of this study was to identify the relation between teachers' ethical leadership perception towards school managers and organizational justice and organization cynicism. In the direction of this purpose, it was sought answers for these questions:

1. Is there a significant relation between teachers' ethical leadership and organizational justice and organizational cynicism?

2. Is there any predictor relation between teachers' perception of ethical leadership, and organizational justice and organizational cynicism?

3. In the interaction of the teachers' ethical leadership perception and organizational cynicism, does organizational justice have a meditator effect?

\section{Method}

\subsection{Design of the Study}

In this study, one of the general scanning methods, relational research method was used. Relational scanning models are used for determining existence or degree of co-change among

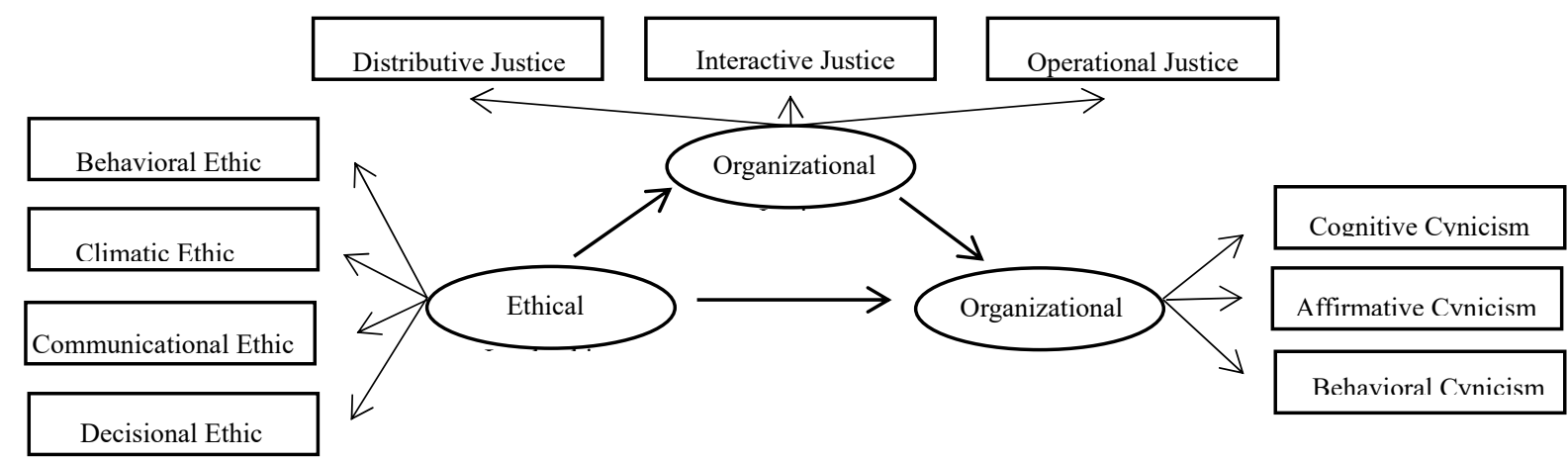

two or more variables (Karasar, 2012).

Figure 1. Model of the Study

In this study, independent variables are ethical leadership and its sub categories (communicational, climatic, behavioral, decisional ethic). Dependent variables are organizational justice and sub categories (distributive, interactional, operational justice), and organizational cynicism and its sub categories (cognitive, affirmative and behavioral). However, organizational justice is both dependent and independent variable because it has direct and indirect impact on organizational cynicism.

\subsection{Sampling}

Participants of this study were middle school teachers who are working in 2014-2015 school calendar at the Osmaniye city center. In the Osmaniye city and county centers, 2109 middle school teachers are working. In this study, purposive sampling was used because in order to create an ethical leadership behavior perception for teachers, it was required to be studied with same schools and same school principals at least one year. 
385 teachers in the city center of the Osmaniye were sample with regarding representativeness ratio. In the demographic information of the sample teachers, it is observed that 177 of the samples were male (46\%), and 208 of the samples were female (54\%). 152 teachers $(39.5 \%)$ were working for $1-10$ years, 151 teachers $(39.2 \%)$ were 11-20 years, and 82 teachers $(21.3 \%)$ were working for more than 21 years. 346 of teachers were married $(89.9 \%)$ and 39 of the teachers $(10.1 \%)$ were single. 69 of the teachers $(17.9 \%)$ were between 22-30 years old, 193 teachers (50.1\%) were between 31-40 years old and 123 teachers $(31.9 \%)$ older than 41.

\subsection{Data Gathering Tools}

Four surveys were used in this study. In the first survey, there are 8 questions related with participants' descriptive variable such as gender, seniority, seniority in the current school, age, branch, graduated major, and school type. In the second section, there was ethical leadership scale, which includes 44 points and 4 dimensions. In the third section, there was organizational justice scale, which consists of 24 points and 3 dimensions, and in the fourth section, there was organizational cynicism scale which is composed of 13 points and 3 dimensions.

In order to determine construct validity of the variables in the scales, dimension(s) of the variables should be identified (Gerbing \& Anderson, 1988: 186). Reliability and validity of the measurement tools should be shown by doing tests. Degree of freedom of random error during measurement indicates reliability (Büyüköztürk, Çakmak, Akgün, Karadeniz \& Demirel, 2013). Confirmatory factor analysis should be done in order to analyze reliability and validity of the scales (Churchill, 1979).

It is observed that reliability and validity studies of the scales used in this study were done in the previous studies. In order to determine whether scales used in this study can be verified or not for our sampling group, confirmatory factor analysis was done for each scale and model. In addition, Cronbach's Alpha reliability coefficient was examined for each scale.

In order to measure teachers' ethical leadership level, "Ethical Leadership Scale" developed by Yilmaz (2005) was used. Explicit factor analysis consists of four factors like in the original study: "Behavioral Ethic", "Climatic Ethic", "Communicative Ethic" and "Decisional Ethic". Sum of variance, explained by four factors is $73.104 \%$. First factor (communicative ethic) explains 21.268\% variance, second factor (climatic ethic) explains $18.225 \%$, third factor (behavioral ethic) explains $17.113 \%$, and fourth factor (decisional ethic) explains $16.498 \%$ variance. Reliability coefficient is of the scale was calculated as .98 . This value was found as .96 for communicative ethic, .97 for climatic ethic, .96 for behavioral ethic, and .95 for decisional ethic.

Moorman's (1991) "Organizational Justice Scale" was used in order to measure teacher's organizational justice level. There are three dimensions in the scale: operational justice, interactional justice and distributive justice. Sum of variance explained by three factors is $28.622 \%$. First factor (operational justice) explains $28.622 \%$ of the variance, second factor (interactional justice) explains $26.332 \%$, and the third factor (distributive justice) explains $23.039 \%$. Total reliability coefficient of the scale was calculated as .97 . In terms of sub 
categories, this value is .95 for operational justice, .95 for interactional justice, and .96 distributive justice.

In this study, Organizational Cynicism Scale was used that is develop by Brandes (1997) and modified to Turkish by Kalagan (2009). Organizational cynicism scale evaluated in three categories: "Cognitive Cynicism", “Affirmative Cynicism” and "Behavioral Cynicism”. Total variance explained by these three factors is $74.743 \%$. First factor (cognitive cynicism) explains $31.109 \%$ of the variance, second factor (affirmative cynicism) explains $22.650 \%$, and third factor (behavioral cynicism) explains 20,983\%. This scale's total reliability coefficient was calculated as .93. For the sub categories, this value is .93 for cognitive cynicism, .89 for affirmative cynicism, and .82 for behavioral cynicism.

According to Terrblanche and Boshoff (2006), confirmative factor analysis is a statistical analytical method that is used for determining reliability and validity level of the scales that are used for measuring conceptual structures that are developed based theories or previously done applied studies. (Avcilar, 2013).

Table 1. Result of Scales Confirmative Factor Analysis

\begin{tabular}{lcccccc} 
SCALE & $\Delta \chi 2$ & $\mathrm{sd}$ & $\Delta \chi 2 / \mathrm{sd}$ & $\mathrm{RMSEA}$ & $\mathrm{CFI}$ & IFI \\
Ethical Leadership & $2229.035^{*}$ & 880 & 2.533 & .063 & .929 & .929 \\
Organizational Justice & $808.669^{*}$ & 243 & 3.328 & .078 & .947 & .947 \\
Organizational Cynicism & $172.793^{*}$ & 53 & 3.260 & .077 & .968 & .969 \\
\hline Model & $\mathbf{9 5 . 6 0 8 *}$ & $\mathbf{3 0}$ & $\mathbf{3 . 1 8 7}$ & $\mathbf{. 0 7 5}$ & $\mathbf{. 9 8 1}$ & $\mathbf{. 9 8 1}$ \\
$* \mathrm{p}<.00$ & & & & & & \\
\hline
\end{tabular}

Chi-square $(\chi 2)$ value of the Ethical Leadership Scale was calculated as 2229.035 at the 880 degree of freedom, and it was statistically significant $(p=.000)$. Corrected chi-square, which is suggested to be between 1-5, was founds as 2.533. Root mean square Error of approximation (RMSEA) was found .063. It is smaller than " $<.08$ " value, which is acceptable value. Indicators of financial integration (IFI) is .947 and confirmatory fit index (CFI) is .929, which is higher than suggested " $\geq 0.95$ " value.

For the Organizational Justice Scale, Chi-square $(\chi 2)$ was calculated as 808.669 at the 243 degree of freedom, and it was statistically significant $(\mathrm{p}=.000)$. Corrected chi-square, which is suggested to be between 1-5, was founds as 3.328. Root mean square Error of approximation (RMSEA) was found .078. It is smaller than " $<.08$ " value, which is acceptable value. IFI is .947 and CFI is .947 , which is higher than suggested " $\geq 0.95$ " value.

For the Organizational Cynicism Scale, Chi-square $(\chi 2)$ was calculated as 172.793 at the 53 degree of freedom, and it was statistically significant $(\mathrm{p}=.000)$. Corrected chi-square, which is suggested to be between 1-5, was founds as 3.260. RMSA was found .077. It is smaller than " $<.08$ " value, which is acceptable value. Indicators of financial integration is .947 and confirmatory fit index is .968 , which is higher than suggested " $\geq 0.95$ " value.

According to result of the analysis, corrected chi-square value is an acceptable value for each of the three variables. Observed data's fix index values are appropriate for suggested model 
and findings are at the acceptable level. This indicates that the model that that in composed by these variables are is appropriate for the gathered data.

\subsection{Data Gathering and Analysis}

Ethical leadership Scale, Organizational Justice Scale, and Organizational Cynicism Scale were applied for 385 participant teachers that is selected randomly among schools which are located in the target area. Scales' internal consistency and reliability evaluation was done according to Cronbach's alpha and confirmatory factor analysis result findings. Data processing was done by using the SPSS and AMOS software. Descriptive analysis related with variables done by using SPSS 18 software. Test of the model that was used for determining effect of ethical leadership on organizational cynicism and organizational justice was tested by AMOS22 software.

\section{Findings and Discussion}

1. Is there a significant relation between teachers' ethical leadership and organizational justice and organizational cynicism?

In the Table 2, the relation between ethical leadership, organizational justice and organizational cynicism variables is shown. In addition, it shows that the relation between these variable's sub-dimensions and the sub-dimensions' average score and standard deviation. 
Table 2. Basic Variable's Average, Standard Deviation and Binary Correlation

\begin{tabular}{|c|c|c|c|c|c|c|c|c|c|c|c|c|c|c|c|}
\hline & & $\mathrm{X}$ & SS & 1 & 2 & 3 & 4 & 5 & 6 & 7 & 8 & 9 & 10 & 11 & 12 \\
\hline 1 & $\begin{array}{l}\text { Climatic } \\
\text { Ethic }\end{array}$ & 3.804 & .931 & & & & & & & & & & & & \\
\hline 2 & $\begin{array}{l}\text { Communicationa } \\
\text { Ethic }\end{array}$ & 3.922 & .901 & $.878 * *$ & & & & & & & & & & & \\
\hline 3 & $\begin{array}{l}\text { Decisional } \\
\text { Ethic }\end{array}$ & 4.107 & .857 & $.829 * *$ & $.884 * *$ & & & & & & & & & & \\
\hline 4 & $\begin{array}{l}\text { Behavioral } \\
\text { Ethic }\end{array}$ & 4.033 & .941 & $.743 * *$ & $.790 * *$ & $.775 * *$ & & & & & & & & & \\
\hline 5 & $\begin{array}{l}\text { Ethical } \\
\text { Leadership }\end{array}$ & 3.967 & .842 & $.929 * *$ & $.956 * *$ & $.936 * *$ & $.893 * *$ & & & & & & & & \\
\hline 6 & $\begin{array}{l}\text { Operational } \\
\text { Justice }\end{array}$ & 3.742 & .952 & $.810 * *$ & $.781 * *$ & $.738 * *$ & $.694 * *$ & $.814 * *$ & & & & & & & \\
\hline 7 & $\begin{array}{l}\text { Interactional } \\
\text { Justice }\end{array}$ & 3.861 & .992 & $.820 * *$ & $.830 * *$ & $.793 * *$ & $.761 * *$ & $.863 * *$ & $.829 * *$ & & & & & & \\
\hline 8 & $\begin{array}{l}\text { Distributive } \\
\text { Justice }\end{array}$ & 3.383 & 1.222 & $.670 * *$ & $.586^{* *}$ & $.544 * *$ & $.542 * *$ & $.632 * *$ & $.676^{* *}$ & $.719^{* *}$ & & & & & \\
\hline 9 & $\begin{array}{l}\text { Organizational } \\
\text { Justice }\end{array}$ & 3.662 & .958 & $.836 * *$ & $.794 * *$ & $.749 * *$ & $.723 * *$ & $.836 * *$ & $.904 * *$ & $.925 * *$ & $.897 * *$ & & & & \\
\hline 10 & $\begin{array}{l}\text { Affirmative } \\
\text { Cynicism }\end{array}$ & 2.071 & 1.003 & $-.357 * *$ & $-.344 * *$ & $-.357 * *$ & $-.303 * *$ & $-.366^{* *}$ & $-.309 * *$ & $-.324 * *$ & $-.274 * *$ & $-.330 * *$ & & & \\
\hline 11 & $\begin{array}{l}\text { Cognitive } \\
\text { Cynicism }\end{array}$ & 2.244 & 1.003 & $-.503 * *$ & $-.478 * *$ & $-.454 * *$ & $-.437 * *$ & $-.504 * *$ & $-.462 * *$ & $-.494 * *$ & $-.418 * *$ & $-.502 * *$ & $.675^{* *}$ & & \\
\hline 12 & $\begin{array}{l}\text { Behavioral } \\
\text { Cynicism }\end{array}$ & 2.577 & .945 & $-.335^{* *}$ & $-.286 * *$ & $-.276 * *$ & $-.273 * *$ & $-.316 * *$ & $-.289 * *$ & $-.253 * *$ & $-.264 * *$ & $-.295^{* *}$ & $.559 * *$ & $.628 * *$ & \\
\hline 13 & $\begin{array}{l}\text { Organizational } \\
\text { Cynicism }\end{array}$ & 2.297 & .851 & $-.462 * *$ & $-.429 * *$ & $-.421 * *$ & $-.392 * *$ & $-.459 * *$ & $-.410 * *$ & $-.416^{* *}$ & $-.370 * *$ & $-.436 * *$ & $.865^{* *}$ & $.891 * *$ & $.837 * *$ \\
\hline
\end{tabular}

$* * \mathrm{p}<.01$

In the Table 2, it can be observed that there is significant high positive relation $(\mathrm{r}=.836$, $\mathrm{p}<.01$ ) between teacher's ethical leadership perception and organizational justice, and medium negative significant relation $(\mathrm{r}=-.459, \mathrm{p}<.01)$ with organizational cynicism. In addition, there is a medium negative and significant relation $(\mathrm{r}=-.459, \mathrm{p}<.01)$ between organizational justice and organizational cynicism. According to this finding, when teachers' ethical leadership perception level increases, organizational justice level increases. At the same time, when ethical leadership and organizational justice level increase, organizational cynicism decreases.

When it is examined subcategories of the variables, it is observed that there is a positive significant relation between ethical leadership and organizational justice's subcategories. When teachers' perception of ethical leadership subcategories increases, organization justice sub categories increases. In addition, level of ethical leadership and level of organizational 
justice's subcategories have negatively significant relation with organizational cynicism's subcategories. In the other words, when value of any subcategory of the ethical leadership and organizational justice variables increases, values of the organizational cynicisms' subcategories decrease.

2. Is there any predictor relation between teachers' perception of ethical leadership, and organizational justice and organizational cynicism?

In the Table 3, It is shown that the relation between subcategories of the ethical leadership behaviors, organizational cynicism and organizational justice. Organizational justice's sub categories.

Table 3. Fit Index Values and Regression Analysis Results

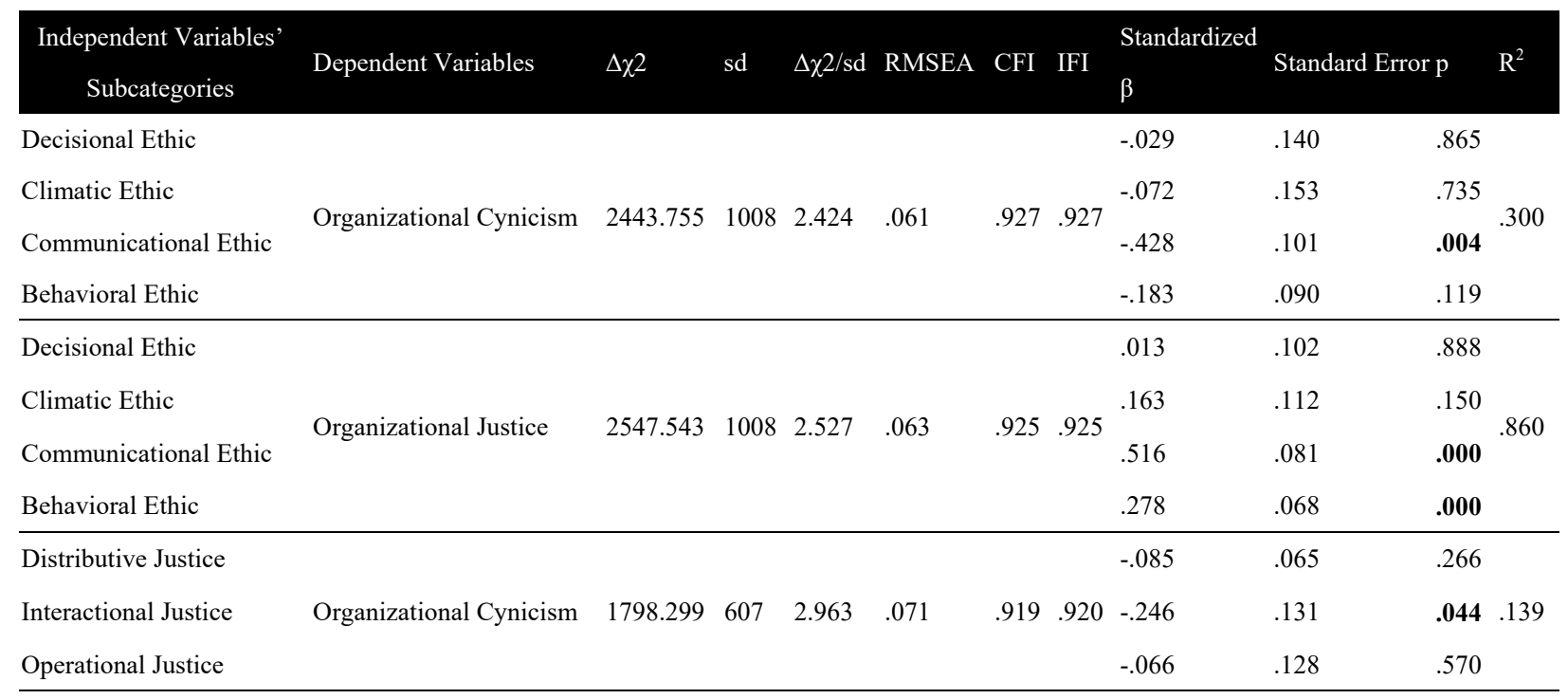

One of the subcategories of the ethical leadership, communicational leadership predicts organizational cynicism's average significantly and negatively $(\beta=-.428, p<.001) .30 \%$ of the variance of the organizational cynicism's general average can be explained by teachers' ethical leadership perception $\left(\mathrm{R}^{2}=.300\right)$. According to this, if school a principal does his/her job in a responsible manner, be enthusiastic about learning, rewards success fairly, try to increase vocational effectiveness, has a love-based approach and gives teachers concrete goals, then teacher can feel less organizational cynicism.

From subcategories of ethical leadership, communicational leadership $(\beta=.516, p<.001)$ and behavioral leadership $(\beta=.278, \mathrm{p}<.001)$, predict organizational leadership's general average significantly and positively. $86 \%$ of the variance of the organizational justice general average can be explained by teachers' ethical leadership perception $\left(\mathrm{R}^{2}=.860\right)$. When Beta value is examined, communicational ethic predicts organizational justice better than behavioral ethic. Based on this, it can be concluded that if a school principal is honest, sincere, compassionate, brave, caring for individual rights in addition to have leadership characteristics that decrease organizational cynicism, then, organizational justice can increase.

Interactional justice, one of the subcategories of the organizational justice, predicts general average of the organizational cynicism significantly and negatively $(\beta=-.246, p<.001)$. 


\section{Macrothink

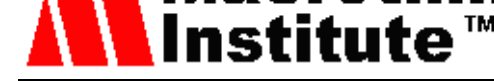

Teachers' organizational justice perception explains $13.9 \%$ of the variance of the organizational cynicisms' general average $\left(\mathrm{R}^{2}=.139\right)$. According to this, when school leaders care about teachers' thoughts, support teachers about their plans and goals, and provide feedback for teachers, teachers experience less organizational cynicism.

3. In the interaction of the teachers' ethical leadership perception and organizational cynicism, is organizational justice has a meditator effect?

According to Baron and Kenny, in order to be able to talk about meditator effect, (1) independent variable should predict meditator variable significantly, (2) independent variable should predict dependent variable significantly, and (3) when meditator variable and independent variable's effect on dependent variable included in the regression equation, there should be a significant relationship (Simsek, 2007).

In this study, the model in figure 2 was created for testing whether level of organizational justice is a meditator for the relation between teachers' ethical leadership perception and organizational cynicism.

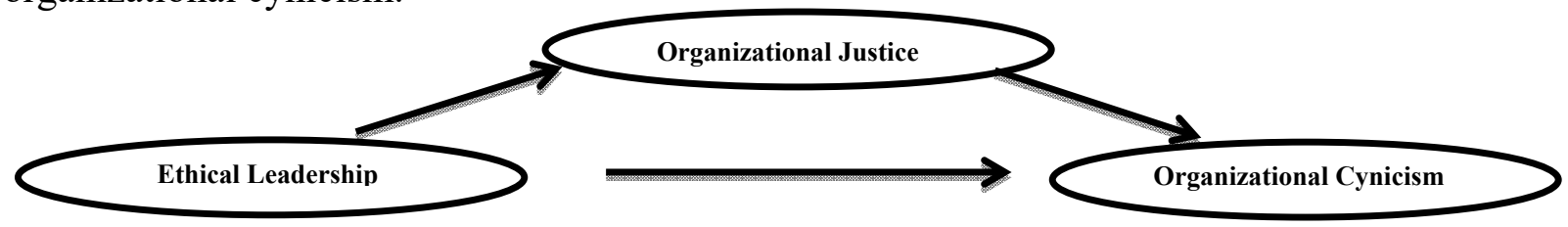

Figure 2. Meditator Test Model

In order to satisfy meditator condition, firstly we need analyze separately ethical leadership variables, organizational justice and organizational cynicism variables. Moreover, we need to be able to conclude that the relation between them is significant.

Table 4. Direct Effect Analysis Results

\begin{tabular}{lllcccc}
\hline \multirow{2}{*}{ Direct Effect: Road coefficients without meditator } & \multirow{2}{*}{ Road Coefficient } & Standard & \multicolumn{2}{c}{ T- } & P- \\
\cline { 5 - 9 } & & & Error & Value & Value \\
\hline Ethical Leadership & $--->$ & Organizational Justice & .93 & .050 & 19.810 & .000 \\
\hline Ethical Leadership & $--->$ & Organizational Cynicism & -.53 & .056 & -9.270 & .000 \\
\hline
\end{tabular}

According to table 4, there is a positive, significant relation between variable ethical leadership and meditator variable organizational cynicism (road coefficient $=-.53, \mathrm{sh}=.056$, $\mathrm{t}=-.9 .270, \mathrm{p}<.001)$.

Lastly, organizational justice variable added between independent variable ethical leadership and dependent variable organizational cynicism. Model was tested by using AMOS22 software. 
Table 5. Meditator Effect Analysis

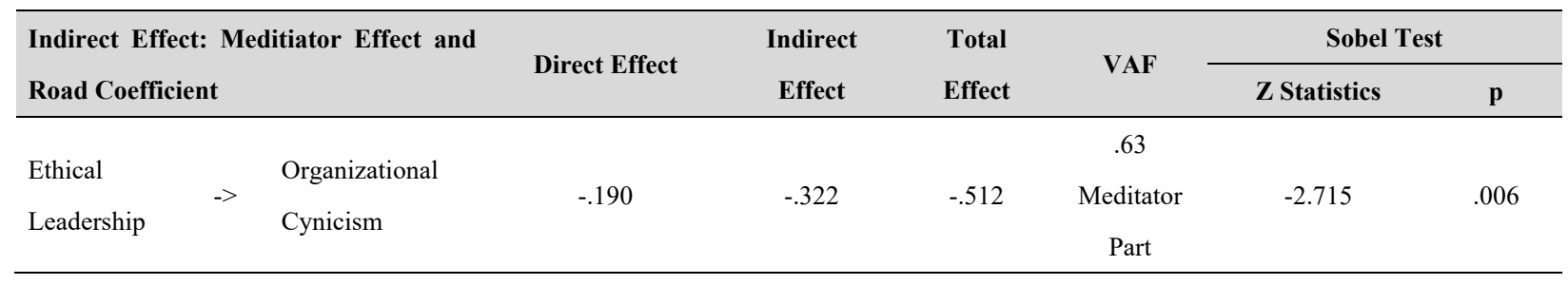

In order to admit there a meditator effect, whether the indirect effect of meditator variable and independent variable is significant or not should be tested. It can be done by using Sobel test (Sobel, 1982). As shown in Table 5, Sobel test results, which is done for testing statistical significance of organizational justice variable and meditator effect, is significant $(Z=-2.715$, $\mathrm{p}<.05)$.

Variance Account For (VAF) value is a method used for examining whether meditator effect exist or not. This value is calculated by using the formula of indirect effect/total effect. If the result is .80 or above, it is a complete meditator effect. If the result is between $.20-.80$, it is partial meditator effect. When VAF is under .20, this shows that there is no meditator effect (Hadi, Naziruddin, \&Ilham, 2016). In this study, VAF value was found as .63.

When direct effects between variables analyzed after organizational justice added to model, it was observed that the effect of teachers' ethical leadership perception on organizational cynicism level has decreased from -.53 to -.19 . After organizational justice added to the model, effect of organizational decreased. This shows that organizational justice level is a partial meditator in the relation. In the other words, school leaders' ethical leadership behaviors have a direct effect and indirect effect via organizational justice on organizational cynicism.

\section{Discussion and Results}

In this study, firstly, from teachers' perspective, school leaders' ethical behavior performing level was examined. According to findings, school leaders perform ethical leadership I a good level. From the perspective of teachers' ethical leadership, highest average score belongs to decisional ethic, then behavioral ethic, then communicational ethic and lastly climatic ethic. These findings are consistent with findings of Cemaloğlu\&Kılınç (2012), Gülcan, K1lıç\&Çepni (2012), Uğurlu (2012), \&İskele (2009). It was found that teachers' organizational justice perception is high. When result of subcategories was examined, interactional justice had the highest average, distributive justice had the lowest average. This finding is consistent with Sahin's (2014) study of organizational identity, organizational image, organizational identification and organizational justice in high schools. According to this, school leaders care more about interaction with teachers, are understanding and fair and towards teachers and care about teachers' rights. It was observed that organizational cynicism level of the teachers was in rare level. When the average of the organizational cynicism considered, cognitive cynicism has the highest average, then affirmative cynicism and behavioral cynicism in order. These results are similar with study of Yüksek (2015) and Yildiz (2013). 
Teacher high organizational cynicism perception affects negatively education process. That's why, school leaders should identify teachers that have high organizational cynicism perception in order to prevent possible problems and develop strategies solving this issue.

In this study, it was concluded that there is a significant, positive relation between ethical behaviors of teachers' perception and organizational. Moreover, there is a positive correlation among all subcategories. These findings are similar to findings of the studies of Ayık, Yücel and Savaş (2014), Acar, Kaya and Şahin (2012), Yeşiltaş, Çeken and Sormaz (2012), Yıldırım (2010), and Uğurlu (2009). When importance of teachers' ethical leadership perception increase for themselves, not only organizational justice level but also but also subcategories of organizational justice, which are decisional ethics, climatic ethic and communicational ethic, increase. When school leaders pay attention to perform ethical leadership behaviors, teachers' organizational justice perception will increase in same level. However, in this study, ethical leadership and organizational justice, with their sub categories, have a negative relation with organizational cynicism. Güzel and Ayazlar (2014), Doğan and Uğurlu (2014), Mete (2013), and Efeoğlu and İplik (2011) have found similar results. Performing of the behaviors covering ethics and justice by school leaders will decrease teachers' possible negative attitude and behaviors.

When teachers' ethical leadership perception increase, their organizational justice level increase. School leaders' communicational ethic behaviors predict organization cynicism perception of the teacher considerably. Akatay, Yücekaya and Kisat (2016) has concluded similar results in the study aiming for identifying the relation between ethical leadership and organizational cynicism. According to this result, when school leaders perform ethical leadership behaviors in higher level, teachers fell less anger, complaint and anxiety. On the other hand, decrease in perception of organizational justice causes increase in level of organizational cynicism. Güzel and Ayazlar (2015) reached similar result in their study. Especially, perception of interactional justice is an important predictor of organizational cynicism. When school leaders care about teachers' idea, support for teachers' work goals and plans, and give feedback to teachers, teachers' perception of organizational cynicism decrease related with school. In addition, when school leaders have fair, unbiased, and kind manner, it contributes to decrease of cynicism level.

According to results of the study, increase in school leaders' performing of ethical leadership behavior can be interpreted as increase in teachers' organizational justice perception. Leaders' behavior during school management is be perceived and valued by teachers. One of the outcome of the ethical behaviors, "justice", affects employees' perception of justice in the school (Uğurlu and Üstüner, 2011).

In this study, it was observed that there is a direct relation between ethical leadership and organizational cynicism. Moreover, when organizational justice added to this relation, it was observed that organizational justice is partial meditator variable in this relation. In short, teachers' perception of ethical leadership has an effect on organizational cynicism through organizational justice interaction. In the other words, the relation between ethical leadership and organizational cynicism lost its value when organizational justice added to model. This shows that there are other meditator variables. On the other hand, after adding organizational 
justice to the model, organizational cynicism lost value but still had a significant effect. This shows that organizational justice is a partial variable in this model. In the other words, school leaders' ethical behaviors effects organizational cynicism directly and indirectly via organizational justice.

\section{References}

Acar, K., Kaya, M., \& Şahin, M. (2012). School administrators ethical leadership behavior effects on physical education teachers organizational justice level. Turkish Journal of Sport and Exercise, 14(3), 51-58.

Akan, D., Bektaş, F., \& Yıldırım, İ. (2014). The Relationship between ethical leadership andorganizationalcynicism based on primary teachers` Perceptions. E-Journal of New World Sciences Academy, 9(1), 48-56. https://doi.org/10.12739/NWSA.2014.9.1.1C0605

Akatay, A., Kısat, N. Ç., \& Yücekaya, P. (2016).Effects of manager's ethical leadership behaviors over organizational fairness and cynism: A research over police department in Çanakkale province. Çanakkale Onsekiz Mart University Journal of Administrative Sciences, 14(28), 483.

Andersson, L. M. (1996). Employee cynicism: An examination using a contract violation framework. Human $\quad$ Relations, $\quad 49(11), \quad$ 1395-1418. https://doi.org/10.1177/001872679604901102

Andersson, L. M., \& Bateman, T. S. (1997). Cynicism in the Workplace: Some causes and effects, The Journal of Organizational Behavior, 18, 449-470. https://doi.org/10.1002/(SICI)1099-1379(199709)18:5<449::AID-JOB808>3.0.CO;2-O

Avcilar, M. (2013).The measurement of consumer based retailer equity: A research in Adana. Ankara: Detay Publishing, Turkey

Ayık, A., Yücel, E., \& Savaş, M. (2014).Ethical leadership behaviors of school administrators as predictors of perception of teachers' organizational justice. Abantízzet Baysal University Journal of Education, $14(2)$. https://doi.org/10.17240/aibuefd.2014.14.2-5000091537

Baldwin, S. (2006). Organizational justice. Institute for Employment Studies.

Bernerth, J. B., Armenakis, A. A., Feild, H. S., \& Walker, H. J. (2007). Justice, cynicism and commitment a study of important organizational change variables.The Journal of Applied Behavioral Science, 43(3), 303-326. https://doi.org/10.1177/0021886306296602

Brown, M. E., Treviño, L. K., \& Harrison, D. A. (2005). Ethical leadership: A social learning perspective for construct development and testing. Organizational Behavior and Human Decision Processes, 97(2), 117-134. https://doi.org/10.1016/j.obhdp.2005.03.002

Brown, M.E. \& Trevino, L.K. (2006). Ethical leadership: A review and future directions. The Leadership Quarterly, 17(6), 595-616. https://doi.org/10.1016/j.leaqua.2006.10.004 
Brown, M.E., Trevino, L.K. \& Harrison, D.A. (2005). Ethical leadership: A social learning perspective for construct development and testing. Organizational Behavior and Human Decision Processes, 97, 117-134. https://doi.org/10.1016/j.obhdp.2005.03.002

Büyüköztürk, Ş. K. Çakmak, E. Akgün, Ö. E. Karadeniz, \& Ş. Demirel, F.(2013). Scientific research methods. Ankara: Pegem A Publishing, Turkey

Cemaloğlu, N., \& Kılınç, A. Ç. (2012).The relationship between school principals' ethical leadership behaviors and teachers perceived organizational trust and mobbing. Education and Science, 165(37), 137-151.

Churchill Jr, G. A. (1979).A Paradigm for developing better measures of marketing constructs.Journal of Marketing Research, 64-73. https://doi.org/10.2307/3150876

Çelik, V. (2013). Educational leadership. Ankara: Pegem A. Publishing, Turkey

Dean, J. W., Brandes, P., \& Dharwadkar, R. (1998).Organizational cynicism. Academy of Management Review, 23(2), 341-352.

Eren, E. (2015). Organizational Behavior and Management Psychology. Ankara: Beta Publishing Distribution, Turkey

Folger, R. G., \& Cropanzano, R. (1998). Organizational justice and human resource management, 7. Sage publications.

Freeman, R. E., \& Stewart, L. (2006).Developing ethical leadership.Business Roundtable Institute for Corporate Ethics, 2-15.

Gerbing, D. W., \& Anderson, J. C. (1988).An updated paradigm for scale development incorporating unidimensionality and its assessment.Journal of Marketing Research, 25(2), 186-192. https://doi.org/10.2307/3172650

Greenberg, J. (2011). Organizational Justice: The dynamics of fairness in the workplace. Washington, DC, US: American Psychological Association

Gülcan, M. G., Kılınç, A. Ç., \& Çepni, O. (2012).Examining primary school principals' ethical leadership behaviors according to different variables. Journal of Turkish Educational Sciences, 10(1).

Güzel, B., \& Ayazlar, G. (2014).The effect of organizational justice towards organizational cynicism and job quit intentions: A research on hotels. KMÜ Journal of Social and Economic Research, 16(26), 133-142.

Hadi N. U., Naziruddin, A. \& Ilham S. (2016), Making sense of mediating analysis: a marketing perspective. Review of Integrative Business \& Economics Research, 5(2), 62-76.

Hansen, S. D. (2011). Ethical leadership: A multifocal social exchange perspective. The Journal of Business, 10(1).

Hatcher, T. (2004). Environmental ethics as an alternative for evaluation theory in for-profit business contexts.Evaluation and Program Planning, 27(3), 357-363. https://doi.org/10.1016/j.evalprogplan.2004.04.009 
İnceoğlu, M. (2004). Attitude perception communication. Ankara: Elips Books, Turkey.

İskele, A. (2009). The effect of primary school principals? Ethical leadership behaviors on creative climate in primary schools. Antalya: AkdenizUniversity, Institute of Social Sciences.

James, M. S. L. (2005). Antecedents and consequences of cynicism in organizations: An examination of the potential positive and negative effects on school systems. Unpublished Doctor Dissertation, Florida: The Florida State University College of Business.

Karacaoğlu, K., \& İnce, F. (2013). The effects of positive organizational behavior on organizational cynicism: A case study Kayseri's manufacturing industry. SüleymanDemirel UniversityJournal of Economics and Administrative Sciences, 18(1).

Karasar, N. (2012). Scientific research method: Concepts, principles, techniques. Ankara: Nobel Publication Distribution.

Meydan, C. H., \& Şeşen, H. (2015).Structural equation modeling AMOS applications. Ankara: Detay Publishing.

Özkalp, E. \& Kırel, Ç. (2004).Organizational behavior. Eskisehir: Anadolu University Publications.

Parent, M. (2009). Ethics in leadership: The Call for morality and caring. SetonHall University. ELMP Cohort XI.(http://www.slideshare.net/mikeparent/ethics-paper-2645596) Date of access: 13/10/2016

Pillai, R., Scandura, T. A., \& Williams, E. A. (1999). Leadership and organizational justice: Similarities and differences across cultures. Journal of International Business Studies, 30(4), 763-779. https://doi.org/10.1057/palgrave.jibs. 8490838

Şahin, E. (2014). Organizational identity, organizational image, organizational identification and organizational justice in high schools (Bursa example). İzmir: Ege University, Institute of Social Sciences.

Şimşek, Ö. F. (2007). Introduction to structural equation modeling: Basic principles and LISREL applications. Ankara: Ekinoks Publishing.

Turhan, M. (2007). The effect of ethical leadership behaviors of high school and vocational high school principals on social justice in schools,( $\mathrm{PhD}$ thesis). Elazığ: Firat University, Institute of Social Sciences.

Uğurlu, C. T. (2009). Effects of administrators?Ethical leadership and organizational justice behavior on primary school teachers? Organizational Commitment Level( $\mathrm{PhD}$ thesis). Malatya: Inonu University

Uğurlu, C. T. \& Üstüner, M. (2011).Effects of administrators' ethical leadership and organizational justice behavior on teachers' organizational commitment level.Hacettepe University Journal of Education Faculty, 41(41).

Wilkerson, J. M., Evans, W. R., \& Davis, W. D. (2008).A test of coworkers' influence on organizational cynicism, badmouthing, and organizational citizenship behavior.Journal of 


\section{Macrothink

Applied
Journal of Studies in Education

ISSN 2162-6952 2017, Vol. 7, No. 2

https://doi.org/10.1111/j.1559-1816.2008.00391.x

Yeşiltaş, M., Çeken, H., \& Sormaz, Ü. (2012).Ethical leadership and organizational justice on the effect of organizational workplace deviation. Muğla University Journal of Social Sciences Institute, 28, 18-39.

Y1ldırım, A. (2010). An application on the relationship between ethical leadership and organizational justice. Karaman: Karamanoğlu Mehmetbey University, Institute of Social Sciences.

Y1ldiz, K. (2013). The relationship between organizational commitment and organizational cynicism and organizational dissent.Turkish Studies-International Periodical for the Languages, Literature and History of Turkish or Turkic, 8(6), 853-879.

Y1lmaz, E. (2005). Validity and reliability study of ethical leadership scale. XlV. Educational Science Congress Book, 808-814.

Yidong, T., \& Xinxin, L. (2013). How ethical leadership influence employees' innovative work behavior: A perspective of intrinsic motivation. Journal of Business Ethics, 116(2), 441-455. https://doi.org/10.1007/s10551-012-1509-x

Yüksel, H. (2015). The relationship between organizational cynicism and commitment: An investigation about the primary and middle school teachers. İzmir: Dokuz Eylül University, Institute of Educational Sciences. 